\title{
Feeding preferences of the surgeonfish Zebrasoma flavescens in relation to chemical defenses of tropical algae
}

\author{
Chad R. Wylie, Valerie J. Paul* \\ University of Guam Marine Laboratory, UOG Station, Mangilao, Guam 96923, USA
}

\begin{abstract}
Seaweed preferences of the tropical herbivorous surgeonfish Zebrasoma flavescens were examined in aquarium assays on Guam, in order to examine the role of secondary metabolites in determining its preferences. Of 55 species of macrophytes examined (49 algae, 5 cyanobacteria, 1 seagrass), only 7 species were highly preferred. Seaweed extracts were examined by thin-layer chromatography (TLC) and proton nuclear magnetic resonance (NMR) spectroscopy to determine the presence or absence of secondary metabolites. Extracts from the non-preferred seaweeds and several pure major metabolites from these seaweeds were tested as feeding deterrents by applying them to the surface of Enteromorpha clathrata, a preferred alga. Extracts that contained secondary metabolites and were the most deterrent were from Bryopsis pennata, Chlorodesmis fastigiata, Desmia hornemanni, Microcoleus lyngbyaceus, Liagora farinosa, and Dictyota bartayresii. The deterrent pure metabolites were malygamide A (from $M$. lyngbyaceus), chlorodesmin (from C. fastigiata), pachydictyol A (from $D$. bartaysesil), ochtodene (from $D$. hornemanni), and a fatty acid metabolite isolated from $L$. faninosa. Several extracts which did not contain metabolites based on our chemical analyses were also significantly deterrent including those from Codium geppii, Padina tenuis, Galaxaura oblongata, and Halymenia durvillaei. Extracts from Caulerpa racemosa. Avrainvillea obscura, and Asparagopsis taxiformis contained secondary metabolites yet were non-deterrent. The pure metaboiltes caulerpin, caulerpenyne, and avrainvilleol from $C$. racemosa and $A$. obscura were also non-deterrent. Secondary metabolites appear to account for the low palatability of many of the seaweeds examined. However, not all secondary metabolites were effective deterrents toward this herbivore.
\end{abstract}

\section{INTRODUCTION}

Coral reefs support an abundance of fishes which derive their energy from benthic plants (Ogden \& Lobel 1978). These herbivorous fishes can exert profound influences on coral reef algal communities (Randall 1961, Vine 1974, Ogden \& Lobel 1978. Hay 1981a, 1984, 1985, Lewis 1985, 1986, Carpenter 1986). Some algae survive the intense herbivory of fishes, and it is known that certain algae are consumed while others are avoided by fishes (Hiatt \& Strasburg 1960, Randall 1967, Earle 1972, Tsuda \& Bryan 1973, Hobson 1974, Bryan 1975, Ogden 1976, Ogden \& Lobel 1978, Lobel \& Ogden 1981. Hay 1981a, b, 1984, Littler et al. 1983, Lewis 1985, 1986, Wolf 1985, Paul \& Hay 1986). Jones (1968) noted that of 160 algal genera available to fishes of the family Acanthuridae in Hawaii, only 40 were

\footnotetext{
- Addressee for correspondence
}

found in the fishes' stomachs. Omitting the algae that were rare in stomach contents, acanthurids ate only $20 \%$ of the algal genera available. This suggests that some algae may be unpalatable or deterrent.

Herbivore food preferences are of theoretical and practical interest to ecologists. Food preferences often determine the role of different herbivores in community organization since herbivores can strongly affect plant diversity, distribution, and biomass (Lubchenco \& Gaines 1981). Plant characteristics that may affect preference include morphology (toughness, calcification), nutritional characteristics (caloric, protein, vitamins, nutrients), and chemical composition (feeding stimulants, feeding deterrents). Few studies of marine herbivore food preference have been conducted, thus the relative importance of these factors is not known.

Hundreds of biologically active natural products have been isolated from marine algae (Scheuer 1978-1983, Faulkner 1984, 1986). Recent studies pro- 
vide evidence that algal secondary metabolites function as defenses against herbivorous fishes (Paul \& Fenical 1986, Paul \& Hay 1986, Targett et al. 1986, Paul 1987. Hay et al. 1987a, b, Paul \& Van Alstyne 1987. Paul et al. 1987a, 1988). These results are not surprising considering the well-documented importance of chemical defenses in terrestrial communities. Secondary metabolites produced by terrestrial plants are considered one of the most important defenses against generalist herbivores (Fraenkel 1959, Whittaker \& Feeny 1971, Freeland \& Janzen 1974, Levin 1976, Rhoades \& Cates 1976, Harborne 1977, 1978, Rosenthal \& Janzen 1979, Coley et al. 1985).

Evidence suggests that herbivory constitutes one of the primary selective forces acting on reef seaweeds (Hay 1981a, 1984, 1985, Carpenter 1986, Lewis 1986). The diversity of herbivores on Pacific reefs is great, and it is in these habitats that we find some of the greatest diversity and variation in the production of secondary metabolites by marine algae (Faulkner 1984, 1986, Paul $\&$ Fenical 1987). Individuals and populations of algae vary in their production of secondary metabolites (Paul \& Fenical 1986, Paul \& Van Alstyne 1987), and many tropical algae combine chemical and morphological defenses to effectively deter grazers (Hay 1984, Paul \& Fenical 1986, Paul \& Hay 1986, Paul \& Van Alstyne 1987. Hay et al. 1988).

The acanthurid Zebrasoma flavescens was used in this study to examine the relationships between feeding preferences and secondary metabolite composition of tropical algae. $Z$. flavescens feeds mostly on uncalcified and filamentous types of algae (Jones 1968) and may be deterred by the morphology of many algal species. We asked the following questions: (1) What species of algae are preferred by $Z$. flavescens? (2) Do these preferences vary among individual $Z$. flavescens? (3) Are Z. flavescens feeding preferences related to secondary metabolite composition in the algae? (4) Do the low-preference algae contain deterrent compounds?

\section{MATERIALS AND METHODS}

Collection. Seaweeds used in this study were collected in a variety of reef, reef flat, and lagoon habitats on Guam. Forty-nine different algal species, 5 cyanobacteria (filamentous blue-greens), and 1 seagrass were used in feeding preference tests. We collected species that were abundant enough to use in the preference trials and simultaneously extract for chemical analyses and feeding deterrent assays. Seaweeds were maintained in large, flowing seawater aquaria and were used in preference trials within $24 \mathrm{~h}$ of collection. The plants were never used in the assays if they appeared damaged or discolored.
Acanthurids Zebrasoma flavescens for the study were captured on Guam reefs and were ca 6 to $8 \mathrm{~cm}$ in total length. Between 8 and $13 Z$. flavescens were kept in $500 \mathrm{l}$ flowing seawater aquaria. Two aquaria were divided into 4 cells each, and one was divided into 6 cells. This was done so that each fish could be held and tested individually. Ca 20 individual fish were used during these studies and individuals were reused for several experiments.

Feeding preference. Susceptibility of seaweeds to grazing was examined by inserting small pieces (1 to $2 \mathrm{~cm}$ long) of 7 or 8 different seaweeds, always including Enteromorpha clathrata, into a $0.5 \mathrm{~m}$ length of $3-$ strand polypropylene line. E. clathrata was readily eaten and was placed on the lines to ensure that the fish were feeding normally. Either 6 or 8 Zebrasoma flavescens were used in the preference assays, and replicate lines were placed one at a time with each individual fish. Each fish was offered the same group of algae for 10 or more separate 30 min trials. The order of algae on the ropes was arranged haphazardly and changed for each trial. After each of the 30 min assays, algae were scored as either completely consumed (eaten) or partially remaining (uneaten). To be scored as eaten, algae were totally consumed except for the portion caught between the 3-strand rope. We did not score an intermediate category (half-eaten) because results did not usually fall into this category. Fish tended to eat the species they liked and take few or no bites of the species they did not like. Only 1 species, Caulerpa racemosa, was frequently half-eaten. The percentage of pieces completely consumed for each seaweed was calculated from the number of pieces completely consumed/total pieces offered $\times 100$ for each fish. The mean percentage of pieces completely consumed was the average for all fish.

The preference for any species of seaweed may be relative to the other species offered on the lines. We ranked the species as high, medium, or low preference based on the mean percentage of each species that was eaten (completely consumed): high preference 180 to $100 \%$ eaten); medium preference ( 20 to $79 \%$ eaten); and low preference ( 0 to $19 \%$ eaten). In order to assess if individual Zebrasoma flavescens differed significantly in their feeding preferences for a species of seaweed the number of pieces that were eaten and uneaten were scored for each fish and compared with a $\mathrm{R} \times \mathrm{C}(8 \times 2)$ test for independence using the $G$-test (Sokal \& Rohlf 1981). The null hypothesis tested was that there was no significant difference among individual fish in the proportion of seaweed pieces consumed.

Chemical analysis. The different species of algae were cleaned of epiphytes and homogenized in a blender in a 1:1 mixture of dichloromethane and methanol. 
The extracts were filtered, and solvents were evaporated under vacuum leaving the organic algal extract (usually a viscous oil).

To test whether secondary metabolites existed in the algal extracts, all extracts were analyzed by thin-layer chromatography (TLC). TLC has previously been used to detect secondary compounds in tropical algae (Norris \& Fenical 1986, Paul \& Hay 1986). TLC plates were developed in 2 solvent systems, $100 \%$ dichloromethane and $100 \%$ diethyl ether, to screen for non-polar and more polar metabolites. TLC plates were then viewed under an ultraviolet (UV) lamp to observe any UV activity, and stained with $50 \%$ sulfuric acid to observe color reactions indicative of secondary metabolites.

Limitations in the use of TLC in detecting watersoluble or highly polar metabolites have been discussed (Paul \& Hay 1986). TLC also tells little about the chemical structures of compounds in the extracts unless the compounds can be related to known standards. For these reasons, we also examined the extracts by proton nuclear magnetic resonance spectroscopy (NMR). Known compounds can be readily detected and identified by NMR spectroscopy. Unusual signals in the NMR spectra could indicate the presence of unknown secondary metabolites

Purification of individual metabolites was accomplished by high-performance liquid chromatography (HPLC) with ethyl acetate/hexane solvent mixtures.

Chemical feeding-deterrence assays. Seaweeds that were not preferred and did not have a tough or calcified morphology were tested for feeding-deterrent effects toward Zebrasoma flavescens. The extracts or isolated metabolites were dissolved in diethyl ether and coated on 25 to $30 \mathrm{mg}$ (wet weight) pieces of Enteromorpha clathrata. The E. clathrata was coated with algal extracts at $1 \%$ wet mass (5\% dry mass) which approximates natural concentrations of organic extracts for most uncalcified algae (Paul 1987). Several pure metabolites isolated from the algae were also tested. The final concentration of pure metabolites was $1 \%$ of the dry mass of the E. clathrata. Control pieces of E. clathrata were coated only with diethyl ether.

The extracts and pure metabolites are lipophilic and adhere to the algae after the ether evaporates. Similar methods have previously been used (McConnell et al. 1982, Targett et al. 1986, Hay et al. 1987a, b, Paul 1987. Paul \& Van Alstyne 1987) and the researchers found that organic compounds were not readily lost to seawater.

Four treated and 4 control pieces of Enteromorpha clathrata were attached to opposite ends of one midweighted polypropylene line so that each piece of treated and control algae was equally accessible to Zebrasoma flavescens. Between 8 and 13 individual fish were allowed to graze on the E. clathrata for 1 to $2 \mathrm{~h}$, or until at least half of the total available pieces on each line were eaten. The number of treated and control pieces that were completely consumed were scored for each line. The assays were analyzed by the non-parametric Wilcoxon's Signed-Ranks Test for paired comparisons (Sokal \& Rohlf 1981).

\section{RESULTS}

The results of the assays examining feeding preferences of Zebrasoma flavescens are shown in Table 1. The presence (+) or absence (-) of secondary metabolites and the presence of calcification (C) are also indicated. Of 55 species of macrophytes tested, 42 species were of low preference. Of these low-preference seaweeds, 32 were never completely eaten. Seven species of algae were highly preferred by $Z$. flavescens. These highly preferred algae did not produce secondary metabolites. The presence of secondary metabolites in the seaweeds is related to low susceptibility to $Z$. flavescens. No high-preference seaweeds and only 2 medium-preference seaweeds produced secondary metabolites while 7 species of high- and 5 species of medium-preference seaweeds did not produce secondary metabolites. Thirteen species of uncalcified low preference seaweeds produced secondary metabolites while 12 species did not (Table 1). These differences between algal-preference groups are significant using a $3 \times 2$ Contingency Table Analysis and the $G$-test $\left(\chi^{2}=\right.$ $8.98, p<0.025)$. For these calculations, we omitted the highly calcified species that might be morphologically defended from grazing.

All of the highly preferred algae were uncalcified, as were most of the medium-preference algae. Zebrasoma flavescens did not consume any highly calcified algae such as Halimeda spp., Tydemania expeditionis, or Mastophora rosea (Table 1). Galaxaura oblongata, G. marginata, Liagora spp., and Padina tenuis were more lightly calcified and less than $10 \%$ of the individual pieces were eaten. Species with a tough morphology, such as Sargassum spp. and Turbinaria ornata, were also not consumed. Therefore, morphological defenses appear to be effective deterrents toward this herbivore.

In order to determine if individual Zebrasoma flavescens were differing in their choices of whole algae, a $\mathrm{R} \times \mathrm{C}$ test of independence using the $G$-test was performed. Individual $Z$. flavescens significantly differed in their preferences for only 8 species of algae, viz. Cladophoropsis membranacea, Chaetomorpha antennina, Caulerpa racemosa, Liagora farinosa, Hypnea pannosa, Acanthophora spicifera, Dictyota cervicornis, and Centroceras clavulatum (Table 2).

Twenty-three species of medium and low-preference 
Table 1. Zebrasoma flavescens. Feeding preferences. $N$ : number of trials; + : secondary metabolites present; - : secondary metabolites absent; $\mathrm{C}$ : calcified ${ }_{i}$ ?: presence or absence of secondary metabolites not determined by our assays

\begin{tabular}{|c|c|c|c|}
\hline Algae & $N$ & $\begin{array}{l}\text { Mean \% completely } \\
\text { eaten }( \pm \mathrm{SE})\end{array}$ & Defenses \\
\hline \multicolumn{4}{|l|}{ High preference (> $80 \%$ eaten) } \\
\hline Boodlea composita & 10 & $97 \pm 3.3$ & - \\
\hline Gelidiopsis intricata & 10 & $97 \pm 2.1$ & - \\
\hline Hypnea esperi & 10 & $97 \pm 3.3$ & - \\
\hline Cladophora fascicularis & 13 & $94 \pm 3.2$ & - \\
\hline Acanthophora spicifera & 10 & $93 \pm 6.7$ & - \\
\hline Enteromorpha clathrata & 123 & $90 \pm 1.9$ & - \\
\hline Centroceras clavulatum & 10 & $87 \pm 7.2$ & - \\
\hline \multicolumn{4}{|l|}{ Medium preierence ( $20-79 \%$ eaten) } \\
\hline Chaetomorpha antennina & 13 & $69 \pm 11.1$ & - \\
\hline Gelidiella myrioclada & 8 & $67 \pm 7.5$ & - \\
\hline Cladophoropsis membranacea & 25 & $55 \pm 6.1$ & - \\
\hline Gelidiella sp. & 10 & $38 \pm 7.0$ & - \\
\hline Bryopsis pennata & 10 & $32 \pm 7.9$ & + \\
\hline Liagora farinosa & 10 & $31 \pm 7.9$ &,$+ \mathrm{C}$ \\
\hline Hypnea pannosa & 10 & $30 \pm 9.0$ & - \\
\hline \multicolumn{4}{|l|}{ Low preference $(<19 \%$ eaten) } \\
\hline Caulerpa racemosa & 26 & $13 \pm 3.2$ & + \\
\hline Liagora sp. & 10 & $12 \pm 3.1$ &,$+ \mathrm{C}$ \\
\hline Dictyota cervicornis & 10 & $8 \pm 4.0$ & + \\
\hline Hydroclathrus clathratus & 10 & $7 \pm 3.3$ & - \\
\hline Polysiphonia sp. & 10 & $7 \pm 4.2$ & - \\
\hline Caulerpa sertulanoides & 10 & $5 \pm 5.0$ & + \\
\hline Halymenia durvillaei & 10 & $5 \pm 2.2$ & - \\
\hline Avrainvillea obscura & 10 & $3 \pm 1.6$ & - \\
\hline Galaxaura oblongata & 10 & $3 \pm 2.1$ &,$- \mathrm{C}$ \\
\hline Galaxaura marginata & 10 & $2 \pm 1.7$ &,$- \mathrm{C}$ \\
\hline Calothrix crustacea & 10 & 0 & $?$ \\
\hline Hormothamnion enteromorphoides & 10 & 0 & + \\
\hline Microcoleus lyngbyaceus & 10 & 0 & + \\
\hline Schizothrix calcicola & 10 & 0 & + \\
\hline Schizothrix mexicana & 24 & 0 & + \\
\hline Caulerpa serrulata & 10 & 0 & + \\
\hline Chlorodesmis fastigiata & 13 & 0 & + \\
\hline Codium geppii & 10 & 0 & ? \\
\hline Halimeda discoidea & 10 & 0 &,$+ \mathrm{C}$ \\
\hline Halimeda gigas & 10 & 0 &,$+ \mathrm{C}$ \\
\hline Halimeda incrassata & 10 & 0 &,$+ \mathrm{C}$ \\
\hline Halimeda opuntia & 9 & 0 &,$+ \mathrm{C}$ \\
\hline Tydemania expeditionis & 10 & 0 &,$+ \mathrm{C}$ \\
\hline Boergesenia forbesii & 10 & 0 & - \\
\hline Valonia fastigiata & 13 & 0 & $?$ \\
\hline Neomeris annulata & 10 & 0 & $+\mathrm{C}$ \\
\hline Ectocarpus breviarticulatus & 13 & 0 & - \\
\hline Feldmannia indica & 10 & 0 & - \\
\hline Dictyota bartayresii & 10 & 0 & + \\
\hline Lobophora variegata & 10 & 0 &,$+ \mathrm{C}$ \\
\hline Padina tenuis & 20 & 0 &,$- \mathrm{C}$ \\
\hline Padina tenuis (Vaughaniella) & 10 & 0 & $?$ \\
\hline Sargassum cristaefolium & 23 & 0 & - \\
\hline Sargassum polycystum & 13 & 0 & - \\
\hline Turbinaria ornata & 11 & 0 & - \\
\hline Asparagopsis taxiformis & 10 & 0 & + \\
\hline Galaxaura fasciculata & 10 & 0 &,$- C$ \\
\hline Mastophora rosea & 13 & 0 & $-\mathrm{C}$ \\
\hline Halymenia sp. & 10 & 0 & + \\
\hline Desmia hornemanni & 13 & 0 & + \\
\hline Gracilaria salicornia & 25 & 0 & - \\
\hline Halodule uninervis & 10 & 0 & - \\
\hline
\end{tabular}


Table 2. Zebrasoma flavescens. Differences among 8 individuals in preferences for species of seaweeds. N: number of trials per individual fish; $p$-values determined by $\mathrm{R} \times \mathrm{C}$ contingency table analysis

\begin{tabular}{|c|c|c|c|c|}
\hline \multirow[t]{2}{*}{ Algae } & \multirow[t]{2}{*}{$N$} & \multicolumn{2}{|c|}{ Amount eaten $(\%)$} & \multirow[t]{2}{*}{$p$-value } \\
\hline & & Range & $\bar{X}$ & \\
\hline \multicolumn{5}{|l|}{ Significant differences among fish } \\
\hline Acanthophora spicifera & 10 & $60-100$ & 93 & $<0.001$ \\
\hline Chaetomorpha antennina & 13 & $23-100$ & 69 & $<0.001$ \\
\hline Centrocerus clavulatum & 10 & $60-100$ & 87 & $<0.025$ \\
\hline Cladophoropsis membranacea & 25 & $28-80$ & 55 & $<0.005$ \\
\hline Liagora farinosa & 10 & $10-60$ & 31 & $<0.05$ \\
\hline Hypnea pannosa & 10 & $0-60$ & 30 & $<0.001$ \\
\hline Caulerpa racemosa & 26 & $0-27$ & 13 & $<0.025$ \\
\hline Dictyota cervicornis & 10 & $0-20$ & 8 & $<0.005$ \\
\hline \multicolumn{5}{|l|}{ No differences among fish } \\
\hline Boodlea composita & 10 & $80-100$ & 97 & \\
\hline Gelidiella myrioclada & 8 & $25-100$ & 67 & $0.1>p>0.05$ \\
\hline Bryopsis pennata & 10 & $10-60$ & 32 & $>0.10$ \\
\hline Hydroclathus clathratus & 10 & $0-20$ & 7 & \\
\hline Halymenia durvillaei & 10 & $0-10$ & 5 & \\
\hline Avrainvillea obscura & 10 & $0-10$ & 3 & \\
\hline Gelidiopsis intricata & 10 & $90-100$ & 97 & \\
\hline Hypneá esperi & 10 & $80-100$ & 97 & \\
\hline Cladophora fascicularis & 13 & $77-100$ & 94 & \\
\hline Enteromorpha clathrata & 123 & $83-94$ & 90 & \\
\hline Gelidiella sp. & 10 & $20-60$ & 38 & \\
\hline Liagora sp. & 10 & $0-20$ & 12 & \\
\hline Polysphonia sp. & 10 & $0-20$ & 7 & \\
\hline Caulerpa sertularioides & 10 & $0-30$ & 5 & \\
\hline Galaxaura oblongata & 10 & $0-10$ & 3 & \\
\hline Galaxaura marginata & 10 & $0-10$ & 2 & \\
\hline
\end{tabular}

algae that lacked apparent morphological defenses were extracted and tested as feeding deterrents toward Zebrasoma flavescens. Results of the feeding-deterrence assays are presented in Table 3 . Of the 4 medium-preference algal extracts, Chaetomorpha antennina and Hypnea pannosa were significant attractants (Table 3 ). These 2 extracts contained no secondary metabolites based upon our chemical analyses. The extract from Liagora farinosa contained secondary metabolites and was a significant deterrent as was the major metabolite isolated from L. farinosa (Fig. 1). Bryopsis pennata also contained active secondary metabolites (Paul \& Fenical unpubl.) and was significantly deterrent toward Z. flavescens (Table 3).

Of the low-preference algae, 3 of the non-deterrent algal extracts - those from Caulerpa racemosa, Avrainvillea obscura, and Asparagopsis taxiformis - contained secondary metabolites. The non-deterrent Ectocarpus breviarticulatus, Hydroclathrus clathratus, and Sargassum polycystum did not produce secondary metabolites based upon our chemical analyses. The pure compounds avrainvilleol (isolated from Avrainvillea obscura), caulerpin, and caulerpenyne (isolated from Caulerpa racemosa) (Fig. 1) were also found to be non-deterrent toward Zebrasoma flavescens (Table 3).
The deterrent extracts that did not appear to contain secondary metabolites by our analyses were Codium geppii, both morphological forms of Padina tenuis (the foliose form and the prostrate Vaughaniella form), Galaxaura oblongata, and Halymenia durvillaei. All other algal extracts tested were found to be deterrent and contained secondary metabolites (Tables 1 and 3). The pure metabolite chlorodesmin (from Chlorodesmis fastigiata) (Fig. 1) was a significant deterrent. The alga Dictyota bartayresii produces the metabolite pachydictyol $\mathrm{A}$ as a minor metabolite (Fig. 1). Both the extract and pachydictyol A were significant feeding deterrents (Table 3). The metabolite malyngamide A from the filamentous cyanobacterium Microcoleus lyngbyaceus and a halogenated monoterpenoid isolated from Desmia hornemanni (ochtodene) were also significant deterrents (Fig. 1; Table 3).

\section{DISCUSSION}

The results of this study show that some low preference algae are chemically defended against the herbivore Zebrasoma flavescens. Thus, chemical defenses appear to play an important role in determining the 
Table 3. Zebrasoma flavescens. Results of assays with algal extracts coated on the preferred alga Enteromorpha clathrata. $N$ : number of trials, each with individual fish; value determined by Wilcoxon's Signed-Ranks Test (1-tailed). A 2-tailed test was used to determine the significant attractants

\begin{tabular}{|c|c|c|c|c|c|}
\hline \multirow[t]{2}{*}{ Extract } & \multirow[t]{2}{*}{$N$} & \multicolumn{2}{|c|}{ Mean $\%$ eaten $\pm \mathrm{SE}$} & \multirow{2}{*}{$\begin{array}{c}\text { Grazing } \\
\text { reduced }(\%)\end{array}$} & \multirow[t]{2}{*}{ p-value } \\
\hline & & Control & Treated & & \\
\hline \multicolumn{6}{|l|}{ Attractants } \\
\hline Chaetomorpha antennina & 13 & $40 \pm 10.4$ & $75 \pm 8.0$ & & 0.0085 \\
\hline Hypnea pannosa & 12 & $40 \pm 6.7$ & $69 \pm 6.4$ & & 0.0261 \\
\hline \multicolumn{6}{|l|}{ Deterrents } \\
\hline Bryopsis pennata & 10 & $79 \pm 10.5$ & $10 \pm 4.5$ & 87 & $<0.0049$ \\
\hline Liagora farinosa & 8 & $75 \pm 9.5$ & $28 \pm 5.7$ & 63 & 0.0117 \\
\hline L. farinosa metabolite & 10 & $68 \pm 8.4$ & $25 \pm 11.2$ & 63 & 0.0137 \\
\hline Codium geppi & 13 & $67 \pm 10.4$ & $15 \pm 6.7$ & 78 & $<0.0052$ \\
\hline Padina tenuis & 13 & $81 \pm 10.7$ & $37 \pm 7.3$ & 54 & 0.0052 \\
\hline Padina tenuis (Vaughaniella) & 13 & $75 \pm 9.4$ & $25 \pm 8.5$ & 67 & $<0.0085$ \\
\hline Galaxaura oblongata & 13 & $81 \pm 7.0$ & $17 \pm 7.2$ & 79 & $<0.0040$ \\
\hline Halymenia durvillaei & 13 & $79 \pm 8.4$ & $33 \pm 8.7$ & 58 & 0.0085 \\
\hline Microcoleus lyngbyaceus & 11 & $90 \pm 5.3$ & $54 \pm 10.2$ & 40 & 0.0093 \\
\hline Malyngamide $\mathrm{A}$ & 8 & $75 \pm 8.2$ & $28 \pm 5.7$ & 63 & $<0.0117$ \\
\hline Hormothamnion enteromorphoides & 10 & $67 \pm 9.1$ & $21 \pm 6.8$ & 69 & $<0.0049$ \\
\hline Chlorodesmis fastigiata & 12 & $83 \pm 9.6$ & $31 \pm 8.6$ & 63 & $<0.0046$ \\
\hline ChIorodesmin & 8 & $75 \pm 6.7$ & $16 \pm 6.6$ & 79 & $<0.0039$ \\
\hline Dictyota bartayresii & 12 & $90 \pm 7.8$ & $29 \pm 6.8$ & 68 & $<0.0046$ \\
\hline Pachydictyol A & 10 & $77 \pm 8.7$ & $5 \pm 3.3$ & 94 & $<0.0049$ \\
\hline Dictyota cervicornis & 11 & $63 \pm 9.5$ & $25 \pm 9.5$ & 60 & $<0.0195$ \\
\hline Liagora sp. & 12 & $73 \pm 10.0$ & $31 \pm 9.0$ & 58 & $<0.0212$ \\
\hline Desmia hornemanni & 12 & $90 \pm 7.8$ & $8 \pm 4.4$ & 91 & $<0.0046$ \\
\hline Ochtodene & 8 & $88 \pm 9.5$ & $31 \pm 7.8$ & 65 & $<0.0117$ \\
\hline Halimeda discoidea & 8 & $84 \pm 8.1$ & $31 \pm 10.3$ & 63 & 0.0017 \\
\hline \multicolumn{6}{|l|}{ Non-deterrents } \\
\hline Caulerpa racemosa & 13 & $75 \pm 9.0$ & $46 \pm 9.7$ & 39 & $>0.05$ \\
\hline Caulerpin & 8 & $72 \pm 5.7$ & $59 \pm 14.1$ & 18 & $>0.10$ \\
\hline Caulerpenyne & 8 & $56 \pm 14.8$ & $41 \pm 9.4$ & 27 & $>0.25$ \\
\hline Avrainvillea obscura & 12 & $61 \pm 8.0$ & $44 \pm 9.9$ & 28 & $>0.10$ \\
\hline Avrainvilleol & 8 & $60 \pm 10.7$ & $40 \pm 10.7$ & 33 & $>0.10$ \\
\hline Asparagopsis taxiformis & 12 & $48 \pm 10.4$ & $35 \pm 7.2$ & 27 & $>0.10$ \\
\hline Ectocarpus breviarticulatus & 11 & $69 \pm 9.5$ & $54 \pm 12.3$ & 22 & $>0.10$ \\
\hline Sargassum polycystum & 12 & $58 \pm 7.7$ & $60 \pm 7.2$ & & $>0.25$ \\
\hline Hydroclathrus clathratus & 11 & $35 \pm 9.2$ & $56 \pm 11.0$ & & $>0.10$ \\
\hline
\end{tabular}

food preferences of this herbivore. It appears that fish perceive these deterrents via taste and learn to visually recognize and avoid chemically defended species. Chapman \& Blaney (1979) discuss perception of secondary metabolites by terrestrial animals and suggest that the response of the sense cells to secondary metabolites is innate. A behavioral response, resulting in avoidance or acceptance of the compound, is also often innate, although animals can learn to avoid ingesting secondary plant metabolites after an 'unpleasant' experience.

Five low-preference algae that produced deterrent secondary metabolites were Microcoleus lyngbyaceus, Chlorodesmis fastigiata, Dictyota bartayresii, $D$. cervicornis, and Desmia hornemanni. None of these species were calcified or had other obvious morphological defenses. The cyanobacterium Microcoleus lyngbyaceus produces the metabolites malyngamide $\mathrm{A}$
(Fig. 1) and B (Cardellina et al. 1978, 1979). The extract of the cyanobacterium Hormothamnion enteromorphoides was also an effective feeding deterrent. Although we do not know the chemistry of this seaweed, we did detect the presence of a more polar metabolite by TLC and observed signals in the proton NMR indicative of the presence of secondary metabolites.

The fleshy green alga Chlorodesmis fastigiata is resistant to grazing in areas of intense herbivory (Paul \& Potter unpubl.). Paul (1987) found this algal extract to be an effective deterrent toward natural populations of herbivores. The deterrent effects appear to be due to the major metabolite produced by Chlorodesmis fastigiata, chlorodesmin (Fig, 1; Wells \& Barrow 1979, Paul \& Fenical 1985), which was deterrent in field assays (Paul 1987) and toward Zebrasoma flavescens in the laboratory (Table 3). 


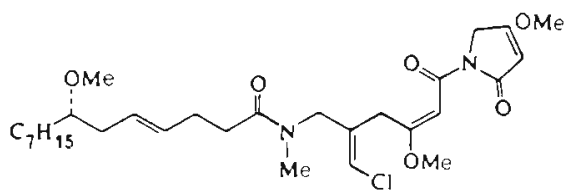

malyngamide A<smiles>CC(=CCCC(CO)CCO[Na])CCC=C(C)CC1COC=C(CO)C1</smiles>

chlorodesmin

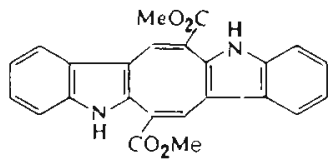

caulerpin

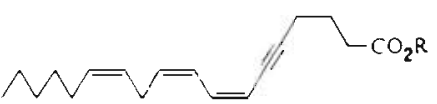

Liagora farinosa acetogenin<smiles>CO/C=C(/C=C/OC)C(C/C=C(\C)C#CC=C(C)C)O[Na]</smiles>

caulerpenyne

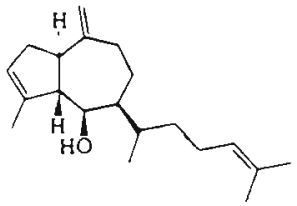

pachydictyol A<smiles>Oc1ccc(O)c(Cc2ccc(Br)cc2)c1</smiles>

avrainvilleol<smiles>[X]C1C(Cl)C(=CCBr)C(Cl)C[C@@H]1Br</smiles>

ochtodene

Fig. 1. Isolated metabolites used in chemical feeding-deterrence assays

The genus Dictyota has been extensively studied by chemists (Gerwick 1981, Faulkner 1984). There are at least 6 different secondary metabolites in $D$. cervicornis as indicated by TLC. The extract from this species deterred Zebrasoma flavescens, yet in areas of high herbivory, this alga is susceptible to many herbivorous fishes (Paul 1987). D. bartayresii and one of its metabolites, pachydictyol A, were deterrents toward $Z$. flavescens (Table 3). D. bartayresii produces at least 10 different diterpenoids of the 'dictyol' ring system (Paul \& Fenical unpubl.) which are all related to pachydictyol A. The actual chemical composition of different populations of D. bartayresii varies on Guam. Fenical (1978) and Faulkner (1984) reviewed the chemistry of the dictyols. Pachydictyol A was a significant feeding deterrent toward herbivorous fishes and the sea urchin Diadema on Caribbean reefs (Hay et al. 1987a), but is ineffective at deterring natural populations of herbivorous fishes on some Guam reefs (Paul unpubl.).

Halogenated monoterpenes have been isolated from Desmia hornemanni (Ichikawa et al. 1974, Burreson et al. $1975 \mathrm{~b}, \mathrm{c}$ ). Hawaiian collections of $D$. hornemanni were reported to produce the cyclic halogenated monoterpenoids chondrocoles $\mathrm{A}$ and $\mathrm{B}$ as major metabolites (Burreson et al. 1975b, c). However, chemical studies of the populations of $D$. hornemanni on Guam indicate that chondrocoles are not present, but a related monoterpenoid ochtodene is the major secondary metabo- lite. Ochtodene has been previously isolated from Ochtodes secundiramea in the Caribbean (McConnell \& Fenical 1978) and was found to be an effective feeding deterrent toward herbivorous fishes in field assays in the Caribbean and on Guam (Paul et al. 1987a). Zebrasoma flavescens was significantly deterred by this algal extract and by ochtodene (Table 3). The whole alga $D$. hornemanni was also avoided by mixed species of juvenile rabbitfish Siganus spinus and $S$. argenteus in studies by Tsuda \& Bryan (1973) on Guam.

The 5 low-preference algae with extracts that were deterrent yet had no secondary metabolites (by TLC and NMR) were Codium geppii, Padina tenuis (both forms), Galaxaura oblongata, and Halymenia durvillaei. The 2 forms of $P$. tenuis are particularly interesting. Lewis et al. (1987) showed that in areas of intense herbivory the prostrate (Vaughaniella) form of Padina jamaicensis persisted. When the herbivores were excluded, the Vaughaniella form made a rapid shift to the foliose form of $P$. jamaicensis. This posed an interesting question. Does the Vaughaniella form of $P$. tenuis produce deterrent secondary metabolites? Zebrasoma flavescens was deterred by the extracts from both morphological forms. The preliminary TLC results did not indicate the presence of secondary metabolites and showed no differences in metabolites between the 2 forms. Most herbivorous fishes readily consume Padina spp. (Hay 1981a, 1984, Lewis 1986), thus the 
deterrent effects were surprising. We extracted both forms of $P$. tenuis again, retested them, and obtained consistent results. Since we could not contribute our results to specific secondary metabolites in the extracts, bioassay-guided isolations of the active components of all 5 extracts are needed.

The 2 medium-preference algae that had deterrent extracts were Bryopsis pennata and Liagora farinosa. Paul \& Fenical (unpubl.) have isolated polar galactolipids from $B$. pennata which appear to be the active feeding deterrents. Zebrasoma flavescens consumed some of the whole $B$. pennata but was significantly deterred by the extract. The $L$. farinosa extract was significantly deterrent toward $Z$. flavescens. The major metabolite has been previously isolated from $L$. farino$s a$ from the Gulf of California and the Caribbean (Paul \& Fenical 1980) and was reported to be ichthyotoxic. This metabolite, an acetogenin bearing an acetylene functionality (Fig. 1), was a significant deterrent toward Z. flavescens (Table 3).

Caulerpa racemosa, Avrainvillea obscura, and Asparagopsis taxiformis all produce secondary metabolites yet were non-deterrent toward Zebrasoma flavescens (Table 3). The metabolites caulerpin and caulerpenyne from Caulerpa racemosa were nondeterrent. These 2 metabolites are found in many species of Caulerpa and have been implicated in chemical defense against herbivores (Paul \& Fenical 1986, Paul \& Hay 1986, Paul et al. 1987b). Caulerpenyne was a feeding deterrent toward the Caribbean parrotfish Sparisoma radians (Targett et al. 1986). However, extracts of several Caulerpa species were not deterrent in field assays toward herbivorous fishes on Guam (Paul 1987). Many Caulerpa species are relatively susceptible to reef fishes in transplant experiments (Hay 1984, Lewis 1985, Paul \& Hay 1986, Paul et al. 1987b). Thus, it appears that herbivore species respond differently to the presence of caulerpenyne.

Avrainvillea obscura produces avrainvilleol (Sun et al. 1983). Both the extract and isolated metabolite were non-deterrent (Table 3). Asparagopsis taxiformis produces halogenated ketones and acetones and halomethanes (Burreson et al. 1975a, McConnell \& Fenical 1977. Woolard et al. 1979). The extract did not deter Zebrasoma flavescens. However, A. taxiformis produces many volatile halomethanes which can be lost by air-drying. McConnell \& Fenical (1977) point out that no extraction method is entirely safe in preserving the volatile constituents of A. taxiformis. Thus, our methods tested only the less-volatile components of the $A$. taxiformis extracts. This alga was completely avoided in the feeding preference studies; thus, it is possible that the volatile halomethanes are effective feeding deterrents.

The green alga Chaetomorpha antennina and the red alga Hypnea pannosa were the only medium-preference algae that had extracts that significantly increased feeding by Zebrasoma flavescens ( $p<0.05$, Wilcoxon's signed-ranks test, 2-tailed; Table 3). Both of the algae were void of secondary metabolites by our analyses, and it is unclear what factors may have hindered feeding during the algal preference tests.

Three low-preference algae which had extracts that did not contain secondary metabolites and were not deterrent were Ectocarpus breviarticulatus, Sargassum polycystum, and Hydroclathrus clathratus. Interestingly, Jones (1968) found Ectocarpus spp. to be a dominant food of Zebrasoma flavescens in Hawaii. Our results showed that $Z$. flavescens from Guam did not eat the whole alga E. breviarticulatus but the extract was non-deterrent.

Zebrasoma flavescens did not consume seaweeds that were calcified or tough. The congener Z. scopas has also been reported to consume primarily filamentous and small fleshy red algae (Robertson \& Gaines 1986). We tested the extracts of only a few species of calcified algae in our assays including Liagora spp. Padina tenuis, Galaxaura oblongata, and Halimeda discoidea. All of these extracts were effective feeding deterrents toward $Z$. flavescens. Z. flavescens appears to be able to detect deterrent secondary metabolites such as halimedatetraacetate (Paul \& Van Alstyne 1987), even though fish would not normally consume Halimeda spp. The frequent combination of chemical and morphological defenses in tropical algae growing in areas of intense herbivory has been previously noted (Hay 1984, Paul \& Fenical 1986, Paul \& Hay 1986, Paul \& Van Alstyne 1987, Hay et al. 1988).

We observed little variation among individual fish in their preferences for seaweeds (Table 2). Most seaweeds were either consumed or avoided, and all fish usually responded similarly. Individuals showed significant differences in their consumption of only 8 of 55 macrophytes. These included mostly high and medium preference algae. Three of these, Liagora farinosa, Caulerpa racemosa, and Dictyota cervicornis, contained secondary metabolites and it is possible that individuals responded differently to the presence of these compounds. In the assays testing the algal extracts and isolated metabolites, we saw no evidence that any fish consistently responded differently to the presence of secondary metabolites. It is possible that Zebrasoma flavescens from other areas of the Pacific could show different feeding preferences.

Many of the major metabolites we isolated (malyngamide A, chlorodesmin, ochtodene, and the Liagora farinosa acetogenin) could account for the deterrence we observed in the crude extracts. However, we did not examine the deterrent effects of other minor metabolites in these extracts, or examine possible 
synergistic effects produced by a combination of different metabolites. Paul et al. (1987a) showed that ochtodene was an effective feeding deterrent toward herbivorous fishes in the Caribbean and on Guam, but it was ineffective toward herbivorous amphipods. It is possible that many seaweeds produce a variety of secondary metabolites because different compounds affect different herbivore species.

This study provides one of the few direct tests of the hypothesis that secondary metabolites are major determinants of the food preferences of a herbivorous reef fish. Most of the macrophyte secondary metabolites that we tested were effective chemical defenses against grazing by Zebrasoma flavescens. Some algal extracts were deterrent toward these herbivores but did not appear to contain secondary metabolites based upon our chemical analyses. Thus, many seaweeds that were not morphologically defended were chemically defended against grazing by this herbivore. A few chemically-rich species were not avoided and their extracts were not deterrent. The ability of herbivores to detect and avoid some compounds and not others has important implications for seaweed chemical defenses. Not all secondary metabolites are feeding deterrents toward herbivorous fishes and herbivores respond differently to algal chemical defenses. The diversity of herbivores tagether with the intensity of browsing and grazing on coral reefs may account for the diversity of secondary metabolites and the chemical variation that exists in tropical seaweeds.

Acknowledgements. We are grateful to Dr Roy Tsuda for assistance in the identification of algae used in this study and to students Carol McMurray and Irene Imanil for assistance with the assays. Critical reading by $\mathrm{C}$. Birkeland, M. Hay, S. Nelson, and 3 anonymous reviewers greatly improved this manuscript. This research was supported by the National Science Foundation (OCE 8600998). HPLC instrumentation was funded by Research Corporation and NSF (BSR 8605299). This is contribution No. 253 of the University of Guan Marine Laboratory.

\section{LITERATURE CITED}

Bryan, P. G. (1975). Food habits, functional digestive morphology, and assimilation efficiency of the rabbitfish Siganus spinus (Pisces, Siganidae) on Guam. Pacif. Sci. 29: 269-277

Burreson, B. J., Moore, R. E., Roller, P. (1975a). Haloforms in the essential oil of the red alga Asparagopsis taxiformis Tetrahedron Lett. 473-476

Burreson, B. J., Woolard, F. X., Moore, R. E. (1975b). Chondrocole $A$ and $B$, two halogenated dimethylhexahydrobenzofurans from the red alga Chondrococcus hornemanni (Mertens) Schmitz. Tetrahedron Lett. 2155-2158

Burreson, B. J., Woolard, F. X., Moore, R. E. (1975c). Evidence for the biogenesis of halogenated myrcenes from the red alga Chondrococcus hornemanni. Chem. Lett. 1111-1114

Cardellina, J. H. II, Dalietos, D., Marner, F. J., Mynderse, J. S., Moore, R. E. (1978). (-)-trans-7(S), methoxytetradec-4- enoic acid and related amides from the marine cyanophyte Lyngbya majuscula. Phytochem. 17: 2091-2096

Cardellina, J. H. II, Marner, F. J., Moore, R. E. (1979). Malyngamide $A$, a novel chlorinated metabolite of the marine cyanobacteria Lyngbya majuscula. J. Am. Chem. Soc. 101: 240-242

Carpenter, R. C. (1986). Partitioning herbivory and its effects on coral reef algal communities. Ecol. Monogr. 56: 343-363

Chapman, R. F., Blaney, W. M. (1979). How animals perceive secondary compounds. In: Rosenthal, G. A., Janzen, D. H. (eds.) Herbivores: their interaction with secondary plant metabolites. Academic Press, New York, p. 161-198

Coley, P. D., Bryant, J. P., Chapin III, F. S. (1985). Resource availability and plant antiherbivore defense. Science 230 : 895-899

Earle, S. A. (1972). The influence of herbivores on the marine plants of Great Lameshur Bay, with an annotated list of plants. In: Collette, B. B., Earle, S. A. (eds.) Results of the Tektite program: ecology of coral reef fishes. Nat. Hist. Mus. Los Angeles County, Sci. Bull. 14: 17-44

Faulkner, D. J. (1984). Marine natural products: metabolites of marine algae and herbivorous marine molluscs. Natural Products Rep. 1: 251-280

Faulkner, D. J. (1986). Marine natural products. Natural Products Rep. 3: 1-33

Fenical, W. (1978). Diterpenoids. In: Scheuer, P. S. (ed.) Marine Natural Products, Vol. II. Academic Press, New York, p. 173-245

Fraenkel, G. S. (1959). The raison d'etre of secondary plant substances. Science 129: 245-259

Freeland, W. J., Janzen, D. H. (1974). Strategies of herbivory in mammals the role of secondary plant compounds. Am. Nat. 108: 269-285

Gerwick, W H. (1981). The natural products chemistry of the Dictyotaceae. Ph.D. dissertation, Scripps Institution of Oceanography, Univ. of California, San Diego

Harborne, J. D. (ed.) (1977). Introduction to ecological biochemistry. Academic Press, New York

Harborne, J. D. (ed.) (1978). Biochemical aspects of plant and animal coevolution. Academic Press, New York

Hay, M. E. (1981a). Herbivory, algal distribution, and the maintenance of between habitat diversity on a tropical fringing reef. Am. Nat. 118: 520-540

Hay, M. E. (1981b). Spatial patterns of grazing intensity on a Caribbean barrier reef: herbivory and algal distribution. Aquat. Bot. 11-97-109

Hay, M. E. (1984). Predictable spatial escapes from herbivory: how do these affect the evolution of herbivore resistance in tropical marine communities? Oecologia (Berl.) 64: 396-407

Hay, M. E. (1985). Spatial patterns of herbivore impact and their importance in maintaining algal species richness. Proc. 5th Int. Coral Reef Symp., Tahiti, Vol. 4: 29-34

Hay, M. E., Fenical, W., Gustafson, K. (1987a). Chemical defense against diverse coral-reef herbivores. Ecology 68: 1581-1591

Hay, M. E., Duffy, J. E., Pfister, C. A., Fenical, W. (1987b). Chemical defense against different marine herbivores: are amphipods insect equivalents? Ecology 68: 1567-1580

Hay, M. E., Paul, V. J., Lewis, S. M., Gustafson, K., Tucker, J. Trindell, R. N. (1988). Does the tropical seaweed Halimeda reduce herbivory by growing at night?: diel patterns of growth, nitrogen content, herbivory, and chemical versus morphological defenses, Oecologia (Berl.) 75: 233-245

Hiatt, R. W., Strasburg, D. W (1960). Ecological relationships of the fish fauna on coral reefs of the Marshall Islands. Ecol. Monogr. 30: 65-127 
Hobson, E. S. (1974). Feeding relationships of teleostean fishes on coral reefs in Kona, Hawaii. Fish. Bull. U.S. 72: 915-1031

Ichikawa, N., Naya, Y., Enomoto, S. (1974). New halogenated monoterpenes from Desmia (Chondrococcus) hornemanni. Chem. Lett. 1974: 1333-1336

Jones, R. S. (1968). Ecological relationships in Hawaiian and Johnston Island Acanthuridae (surgeonfishes). Micronesica 4 : 309-361

Levin, D. A. (1976). The chemical defenses of plants to pathogens and herbivores. A. Rev. Ecol. Syst. 7. 121-159

Lewis, S. M. (1985). Herbivory on coral reefs: algal susceptibility to herbivorous fishes. Oecologia (Berl.) 65: 370-375

Lewis, S. M. (1986). The role of herbivorous fishes in the organization of a Caribbean reef community. Ecol. Monogr. 56: 183-200

Lewis, S. M., Norris, J. N., Searles, R. B. (1987). The regulation of morphological plasticity in tropical reef algae by herbivory. Ecology 68: 636-641

Littler, M. M., Taylor, P. R., Littler, D. S. (1983). Algal resistance to herbivory on a Caribbean barrier reef. Coral Reefs 2: $111-118$

Lobel, P. S., Ogden, J. C. (1981). Foraging by the herbivorous parrotfish Spanisoma radians. Mar. Biol. 64: 173-183

Lubchenco, J., Gaines, S. D. (1981). A unified approach to marine plant-herbivore interactions. I. Populations and communities. A. Rev. Ecol. Syst. 12: 405-437

McConnell, O. J., Fenical, W. (1977). Halogen chemistry of the red alga Asparagopsis. Phytochem. 16: 367-374

McConnell, O. J., Fenical, W (1978). Ochtodene and ochtodiol: novel polyhalogenated cyclic monoterpenes from the red seaweed Ochtodes secundiramea. J. org. Chem. 43: 4238-4241

McConnell, O. J., Hughes, P. A., Targett, N. M., Daley, J. (1982). Effects of secondary metabolites from marine algae on feeding by the sea urchin, Lytechinus variegatus. J. chem. Ecol. 8: 1437-1453

Norris, J. N., Fenical, W. (1986). Natural products chemistry in benthic marine algae: uses in ecology and systematics. In: Littler, M. M., Littler, D. S. (eds.) Handbook of phycological methods. IV: Ecological field methods. Cambridge University Press, Cambridge, p. 121-145

Ogden, J. C. (1976). Some aspects of herbivore-plant relationships on Caribbean reefs and seagrass beds. Aquat. Bot. 2: 103-116

Ogden, J. C., Lobel, P. S. (1978). The role of herbivorous fish and urchins in coral reef communities. Environ. Biol. Fish. 3: $49-63$

Paul, V J. (1987). Feeding deterrent effects of algal natural products. Bull. mar Sci, 41: 514-522

Paul, V J, Fenical, W (1980). Toxic acetylene-containing lipids from the red marine alga Liagora farinosa Lamouroux. Tetrahedron Lett. 21 3327-3330

Paul, V. J., Fenical, W. (1985). New bioactive terpenoids from tropical Pacific marine algae of the family Udoteaceae (Chlorophyta). Phytochemistry 24: 2239-2243

Paul, V J., Fenical, W. (1986). Chemical defense in tropical green algae, order Caulerpales. Mar. Ecol. Prog. Ser 34: $157-169$

Paul, V. J., Fenical, W (1987). Natural products chemistry and chemical defense in tropical marne algae of the phylum Chlorophyta. In. Scheuer, P. S. (ed.) Bioorganic marine chemistry. Springer-Verlag, Berlin, p. 1-29
Paul, V J., Hay, M. E. (1986). Seaweed susceptibility to herbivory: chemical and morphological correlates. Mar. Ecol. Prog. Ser. 33: 255-264

Paul, V. J., Hay, M. E., Duffy, J. E., Fenical, W., Gustafson, K (1987a). Chemical defense in the seaweed Ochtodes secundiramea (Rhodophyta): effects of its monoterpenoid components upon diverse coral-reef herbivores. $J$. exp. mar. Biol Ecol. 114: 249-260

Paul, V. J., Littler, M. M., Littler, D. S., Fenical, W. (1987b) Evidence for chemical defense in tropical green alga Caulerpa ashmeadii (Caulerpaceae: Chlorophyta): isolation of new bioactive sesquiterpenoids. J. chem. Ecol. 13 $1171-1185$

Paul, V. J., Van Alstyne, K. (1987). Chemical defense and chemical variation in the genus Halimeda. Coral Reefs 6 $263-269$

Paul, V J., Ciminiello, P., Fenical, W. (in press). New diterpenoid feeding deterrents from the Pacific green alga

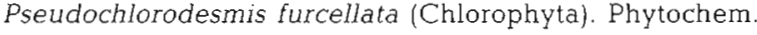
27: 1011-1014

Randall, J. E. (1961). Overgrazing of algae by herbivorous marine fishes. Ecology 42: 812

Randall, J. E. (1967). Food habits of reef fishes of the West Indies. Stud. Trop. Oceanogr. Miami 5: 655-847

Rhoades, D., Cates, R. G. (1976). Toward a general theory of plant antiherbivore chemistry. Rec. Adv. Phytochem. 10: 168-213

Robertson, D. R., Gaines, S. D. (1986). Interference competition structures habitat use in a local assemblage of coral reef surgeonfishes. Ecology 67: 1372-1383

Rosenthal, G. A., Janzen, D. H. (eds.) (1979). Herbivores: their interaction with secondary plant metabolites. Academic Press, New York

Scheuer, P. J. (ed.) (1978-1983). Marine natural products: chemical and biological perspectives, Vols. 1-5. Academic Press, New York

Sokal, R. R., Rohlf, F. J. (1981). Biometry. W. H. Freeman and Co., New York

Sun, H. H., Paul, V. J., Fenical, W. (1983). Avrainvilleol, a brominated diphenylmethane derivative with feeding deterrent properties from the tropical green alga Avrainvillea longicaulis. Phytochem. 22: 743-745

Targett, N. M., Targett, T E., Vrolijk, N. H., Ogden, J. C. (1986). Effect of macrophyte secondary metabolites on feeding preferences of the herbivorous parrotfish Sparisoma radians. Mar. Biol. 92: 141-148

Tsuda, R. T., Bryan, P. G. (1973). Food preferences of juvenile Siganus rostratus and $S$. spinus in Guam. Copeia 1973: 604-606

Vine, P. J. (1974). The effect of algal grazing and aggressive behavior of the fishes Pomacentrus lividus and Acanthurus sohal on coral reef ecology. Mar Biol. 24: 131-136

Wells, R. J., Barrow, K. D. (1979). Acyclic diterpenes containing three enol acetate groups from the green alga Chlorodesmis fastigiata. Experientia 35: 1544-1545

Whittaker, R. H., Feeny, P. (1971). Allelochemics: chemical interactions between species. Science 171.757-770

Wolf, N. G. (1985). Food selection and resources partitioning by herbivorous fishes in mixed-species groups. Proc. 5th Int. Coral Reef Symp. Tahiti, Vol. 4:23-28

Woolard, F. X., Moore, R E., Roller, P. P. (1979). Halogenated acetic acids and acrylic acids from the red alga Asparagopsis taxiformis. Phytochem 18: 617-620 